\title{
Influence of phytophagous mammals environment-forming activity on the soil invertase fermentative activity in conditions of mining impact region
}

\author{
Svetlana Kirienko ${ }^{1}$ - Oleg Didur² - Iryna Loza ${ }^{2}$ - Olexandr Pakhomov ${ }^{1}$ \\ ${ }^{1}$ Department of Zoology and Ecology, Biology, Ecology and Medicine Faculty, Dnepropetrovsk \\ National University, Gagarina av., 72, 49010 Dnepropetrovsk. Ukraine \\ ${ }^{2}$ Institute of Biology, Dnepropetrovsk National University, Gagarina av., 72, 49010 Dnepropetrovsk. \\ Ukraine, e-mail: irinaloza@hotmail.com; didur@ua.fm
}

Keywords: fossorial activity, mammals, invertase, soil fermentative activity.

\section{SUMMARY}

Excretorial and fossorial activity of mammals is an important part of environment-forming activity. Mammals have influences on important biogeocenotic processes, especially on the soil processes. Determination the maintenance of soil invertase as one of diagnostic description the ecological state allowed defining limits of oscillation index in dump areas and in clean (control) native areas. The obtained results of the investigation indicate the soil depth, duration of experiment and type of area influence on soil invertase activity with the high statistical level of significance. Positive influence is revealed on invertase activity changing on dump areas, where an active excretorial and fossorial activity of phytophagous mammals was observed.

\section{INTRODUCTION}

Over 80 deposits of minerals are found in Ukraine; most of them (about $70 \%$ ) is situated in the Kryvorizhsky iron-ore basin. About 90 different industrial works of ferrous metallurgy function in Kryvorizhsky region. As a result of long-term activity metallurgical and chemical enterprises, crisis and catastrophic states of environment can be experienced in the Kryvorizhsky region. Consequences of integrity violation are irreversible transformations of geological environment and hydrosphere.

Complex contamination of environment (soils, air, superficial and underground waters) by industrial toxicants took place in the region. In such local anthropogenic conditions were formed new anthropogenic landscapes and technogen ecosystems (Добровольский, 1982, 1988; Зонн, 1989; Травлеев, 2000; Белова, 2001; Малахов, 2003).

In conditions of technogen pressing the soil surface are covered by different kinds of industrial wastes. Often soil play an important role as a buffer and detoxication medium in the ecosystems. Soil always accumulates different quality of industrial wastes: heavy metals, pesticides, carbohydrates, phenol compositions, acetone, detergents and other chemical contaminants (Долгова, 1999). In conditions of excessive contamination a soils lose functions of detoxication, and destructive processes develop into them. In this situation the industrial wastes get into biogeochemical cycles; they enter into physical and chemical interaction with soil exchange capacity complex, consumed by the soil organisms and plants. This process is accompanied by changes of their toxic level and migratory mobile (Долгова, 1988).

The soils are exposed especially strong technogen pressure in the districts of industrial concerns location, cities, and around transport roads. Technogenic deserts often formed the territories, which are situated near the industrial areas of chemical and metallurgical enterprises, or which are located near to enterprises.

Excretorial and fossorial mammal activity is important part of environment-forming activity of animals. Different kinds of animals always influence on main ecosystem processes, especially on the paedogenesis and processes of forming the soil biological activity (Булахов, 1973; Злотин, 1974; Абатуров, 1980; Булахов, 1998; Пахомов, 2004). As a result of excretorial and fossorial activity of different animals groups is impact on complex of soil-forming processes. When soils are intensively enriches by organic matter, its physical and chemical properties optimize, and the total biological activity raises (Хабиров, 1979; Хазиев, 1982; Булахов, 1987; Булахов, 2006). Thus, environment-forming activity of animals is an important factor for soil-forming process.

The invertase enzyme is necessary constituent of soil biological activity. Therefore the content of this enzyme in the soil is an index of its diagnostic state.

By the effect of invertase the transformation of carbohydrates, and also the destructs of saccharose to glucose and fructose (Хазиев, 1982) is take place by the invertase.

\section{MATERIALS AND METHODS}

The object of research work is environment-forming activity of mammal animals, especially excretorial role of phytophagous mammals and fossorial role of micro-mammals in conditions of Kryvorizhsky iron-ore basin. In 
addition the influence of environment-forming mammal activity is investigated on soil ecological properties (on example of invertase fermentative activity) in conditions of technogen pressure.

Methods of soil fermentative activity determinations were accepted. Experimental information was processed by generally accepted methods of variation statistics.

Experimental site is the territory of Kryviy Rig dumps. Experimental points were located on the territory "Arselor Mittal Steel" which is the most major mine-metallurgic complex of Ukraine with full metallurgical cycle. This enterprise is specialized on the production of armature steel, and also produces agglomerate, concentrate, coke, cast-iron, steel, high-quality and shaped rental, blast-furnace slag.

Investigating area was choosing on territory a dump Dalekiy which belong to "Arselor Mittal Steel". Researchers included three experimental points. On each point were made experiments with bringing on surface animal excrements and experiments without excrements presence. Fresh excrements of phytophagous mammals were brought from the calculation of $1 \mathrm{~kg} / \mathrm{m}^{2}$ of soil. Samples of soil were taken in horizons: $0-5 \mathrm{~cm}, 5-10 \mathrm{~cm}$. On the dump Dalekiy territory barrows of mole rat are observed, that is why specific characteristic of this territory is presence of fossorial activity with mammals. As a clean (control) points, are selected territories which located near native gully Lativka. The field experiments were carried out during one, three and twelve months.

\section{RESULTS AND DISCUSSION}

The results of invertase activity from the control site and from the dump areas are given in the Figure 1.Data of the point \# 1 present the total tendency in changes of soil invertase activity. During the 1 month period on a point \# 1 (a dump Dalekiy, age of the artificial forested planting 20-25 years) in the 0-5 cm level soil layer the invertase activity on areas with mammal excrements has been $0.95 \mathrm{mg} \mathrm{g}^{-1}$ of soil per 24 hours. It is 1.3 times more in comparison with point without influence of mammals.

Figure 1. Influence of phytophagous mammal excretory on the invertase activity of soil (point \# 1: territory of a 20-25 years old artificial forest, "Mittal Steel, Kryviy Rig")

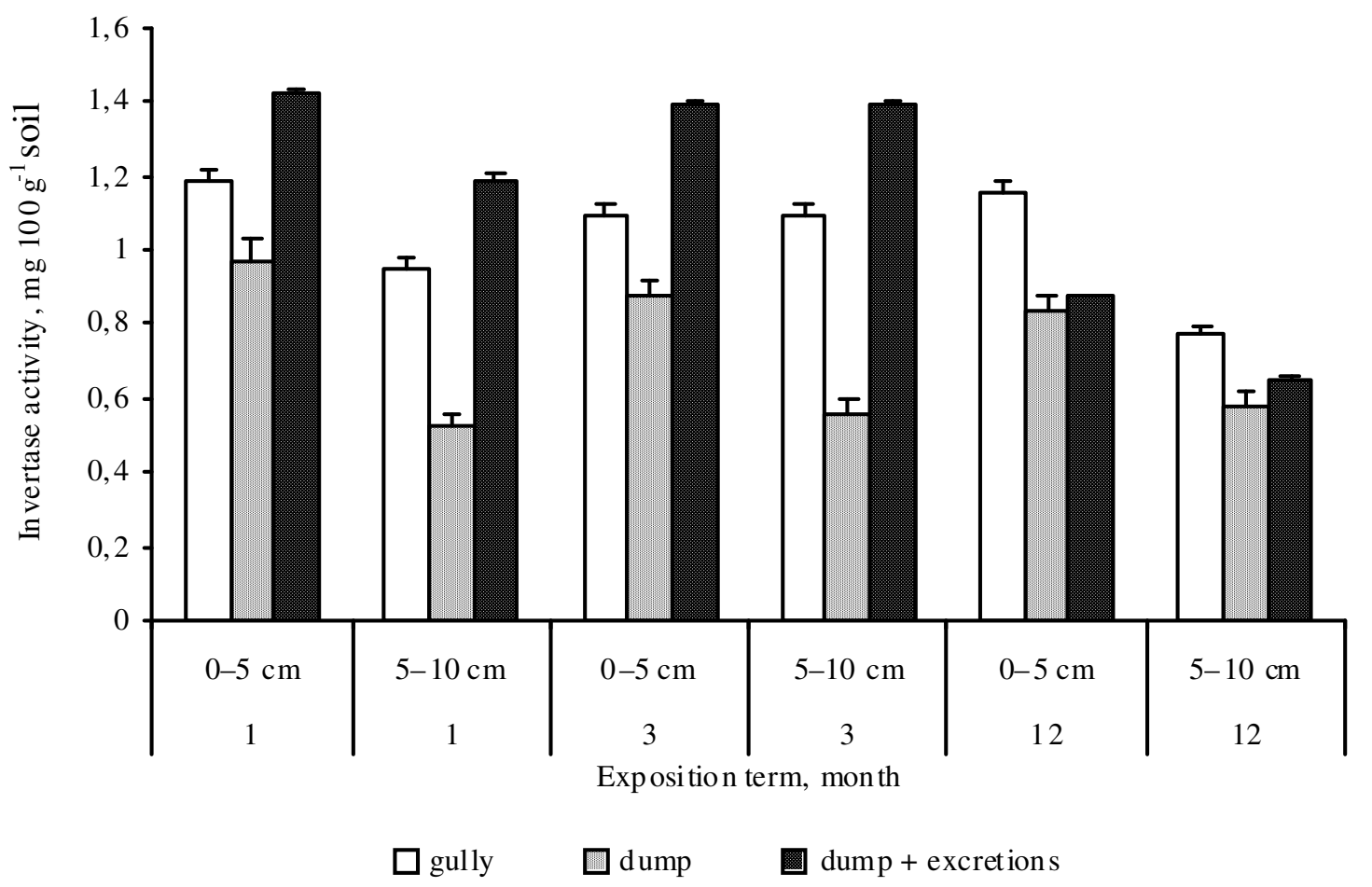

Conventional signs: a gully (native clean area near Lativka village without influence of excretorial activity of phytophagous mammals); a dump (area a dump Dalekiy without excretorial activity of phytophagous mammals); dump + excretions (area a dump Dalekiy with influence of excretorial activity of phytophagous mammals).

Excretorial activity of phytophagous mammals increased the level of invertase activity by 1.2 times compare to the clean areas. Influence of animals excretorial activity on the soil depth $5-10 \mathrm{~cm}$ is similar as layer $0-5 \mathrm{~cm}$. 
Decrease of invertase activity in dump soils without excrements as compared with clean areas in 1.1 times and in 1.8 times in accordance with depths $0-5 \mathrm{~cm}$ and $5-10 \mathrm{~cm}$ (Fig. 1).

12 months after starting of experiment on the soil depth $0-5 \mathrm{~cm}$ where animal excrements were presented by comparison with areas a dump without excrements the index of invertase activity decreased in 1.1 times and in 3 times in comparison with clean areas of gully. Index of invertase activity on this soil depth in dump points without mammals' excrements comparatively with clean points decreased in $0,4 \mathrm{mg} / 100 \mathrm{~g}$ soil (Fig. 1). It has been found out what increase the index of invertase activity on a depth of soil $5-10 \mathrm{~cm}$ in areas with excretorial activity as compared with dump points in 1.2 times and in 3 times by comparison with clean points. Index of invertase activity on the depth $0-5 \mathrm{~cm}$ in dump areas without influence of phytophagous mammals as compared with clean areas goes down in 3 times in the layer of soil $5-10 \mathrm{~cm}$. Thus, invertase activity in dump area \# 1 increased due to influence of excretorial activity of animals, especially on a depth 5-10 cm during 12 months of field experiment.

The statistical analysis of research material is discovered that the depth of soil, the duration of experiment display and the type of area had influence on the invertase activity index. These characteristics have influence on varying of invertase activity index with high statistical level of significance $(\alpha \leq 0.05)$.

It is typical for all areas reliable difference $(\alpha \leq 0.05)$ after a depth: with its increase the invertase activity diminishes. Significant difference is observed for experiments which are contrast on term duration (1 and 12 months and 3 and 12 months; $\alpha \leq 0.05$ ).

It is established that the middle invertase activity diminishes in the course of experiment time that is explained by complete decomposition of excrements during 12 months. They have become stable at the level of $0.67 \mathrm{mg} \mathrm{g}^{-1}$ of soil in 24 hours. Absence of difference in index of middle fermentative activity between 1 and 3 months testifies about active process of organic matter decomposition. Invertase activity is 0.91 and $0.83 \mathrm{mg} \mathrm{g}$ soil $^{-1}$ in 24 hours accordingly.

The type of area stipulated also a specific biochemical reaction regarding the decomposition of organic matter (containing excrements of animals). So there is statistically significant difference $(\alpha \leq 0.05)$ middle invertase activity on dump areas with the animal excrements ( $0.996 \mathrm{mg} \mathrm{g}$ soil $^{-1}$ in 24 hours), in dump areas, without excrements $\left(0.51 \mathrm{mg} \mathrm{g} \mathrm{soil}^{-1}\right.$ in 24 hours), and also between clean (control) point and in the dump area with excrements $(0.90$ and to 0.51 per 24 hours). Middle invertase activity in dump areas with animal excrements $\left(0.996 \mathrm{mg} \mathrm{g} \mathrm{soil}^{-1}\right.$ per 24 hours) is the same than it was in clean (control) area $\left(0.996 \mathrm{mg} \mathrm{g} \mathrm{soil}^{-1}\right.$ in 24 hours).

\section{CONCLUSIONS}

Excretorial (and fossorial) activity of mammals is an important part of environment-forming activity by mammals, which effect on the important biogeocenotical processes, especially the processes taking place in the soils. Determination of soil invertase activity can be one of diagnostic description the ecological state of soil and allow defining a limit of oscillation index in dump areas and in clean (control) native areas.

The obtained results of the investigation indicate the soil depth, duration of experiment and type of area influence on varying of soil invertase activity with the high statistical level of significance. Positive influence is revealed on invertase activity changing on dump areas, where are observed an active excretorial and fossorial activity of phytophagous mammals.

\section{REFERENCES}

Белова Н. А.: 2001. Опыт выявления деструктивных лесных сетей на основе микроморфологического тестирования эдафотопов / Н. А. Белова, А. П. Травлеев // Екологія та ноосферологія. Т. 10, № 1-2. - С. 31-40.

Добровольский И. А.: 1982. Типология железорудных отвалов Криворожского бассейна на основе идей А. Л. Бельгарда / И. А. Добровольский, В. И. Шанда // Биоценологические исследования степных лесов, их охрана и рациональное использование. - Д.: ДГУ, . - С. 30-36.

Добровольський И. А.: 1988. Некоторые закономерности распределения железа в техногенных ландшафтах Кривбасса / И. А. Добровольский, Н. Н. Цветкова, Л. К. Баранова // Мониторинговые исследования лесных экосистем степной зоны, их охрана и рациональное использование. - Д.: ДГУ. С. 69-72.

Зонн С. В., Травлеев А. П.: 1989. Географо-генетические аспекты почвообразования, эволюции и охраны почв. / С. В. Зонн, А. П. Травлеев. - К.: Наук. думка,- 216 с.

Малахов І. М.: 2003. Проблема незворотності трансформації навколишнього середовища Кривбасу / І. М. Малахов // Проблеми екології та екологічної освіти: Матеріали 2 Міжнар. наук.-прак. конф. - Кривий Ріг, - С. 10-18.

Травлеев А. П.: 2000. Деструктивные экологические сети и перспективы их оптимизации / А. П. Травлеев, Н. А. Белова // Питання степового лісознавства та лісової рекультивації земель. - Д.: ДНУ, - С. 5-17.

Долгова Л. Г.: 1999. Ферментативная активность и микробиологические процессы в эдафотопах техногенных регионов / Л. Г. Долгова // Екологія та ноосферологія. Т. 8, № 4. - С. 18-23. 
Долгова Л. Г.: 1988. Активность почвенных уреазы и инвертазы как показатель загрязнения эдафотопов роданистыми и фтористыми соединениями / Л. Г. Долгова, В. Н. Кучма, В. Н. Гришко // Мониторинговые исследования лесных экосистем степной зоны, их охрана и рациональное использование. ДГУ, С. 72-76.

Абатуров Б. Д., Ракова М. В., Середнева Т. А.: 1980. Воздействие малых сусликов на продуктивность растительности в полупустыне // Фитофаги в растительных сообществах. - М.: Наука- С. 11-127.

Булахов В. Л.: 1973. Характеристика средообразующей деятельности позвоночных животных в лесах степной зоны юговостока УССР // Вопросы степного лесоведения: Труды Комплексной экспедиции ДГУ. - Д.: ДГУ,- Вып. 4. - С. 117-125.

Булахов В. Л., Пахомов А. Е.: 1998. Средообразующая деятельность млекопитающих как биотический фактор преждевременной деградации почвенного покрова степных лесов промышленного Приднепровья // Антропогенная деградация почвенного покрова и меры ее предупреждения: Тезисы докл. Всерос. конф. - М- Т. 2. - С. 220-221.

Злотин Р. И., Ходашова К. С. Роль животных в биологическом круговороте лесостепных экосистем. - М.: Наука, 1974. - 200 с.

Пахомов О. Є., Кірієнко С. М.: 2004. Вплив екскреторної діяльності ссавців на ферментативну активність грунту та накопичення гумусу на відвалах гірничорудної промисловості Криворіжжя // Науковий вісник Чернівецького університету. Біологія. Чернівці,. С. 191-197.

Булахов В. Л.: 1987. Роль позвоночных животных в межбиогеоценотических связях в лесных биогеоценозах степной зоны Украины // Охрана и рациональное использование защитных лесов степной зоны. - Д.: ДГУ, - С. 87-92.

Булахов В. Л., Пахомов О. Є.: 2006. Біологічне різноманіття України. Дніпропетровська область. Ссавці (Mammalia). -ДНУ,$356 \mathrm{c}$.

Хабиров И.К.: 1979. Физические свойства и ферментативная активность почв. Экологические условия и ферментативная активность почв. Академия наук СССР. Башкирский филиал института биологии. УФА. Хазиев Ф. Х. Системноэкологический анализ ферментативной активности почв. - М.: Наука, 1982. - С. 11-12. 